\title{
Potential neurological impact of coronaviruses: implications for the novel SARS-CoV-2
}

\author{
Joy D. Iroegbu ${ }^{1}$ - Chibuzor W. Ifenatuoha ${ }^{1} \cdot$ Omamuyovwi M. Ijomone ${ }^{1,2}$ (I)
}

Received: 28 April 2020 / Accepted: 9 May 2020 / Published online: 18 May 2020

(C) Fondazione Società Italiana di Neurologia 2020

\begin{abstract}
Coronaviruses $(\mathrm{CoV})$ are viruses widely known to cause severe respiratory distress due to the prominent clinical symptoms presented. These symptoms, which include fever and dry cough, are frequently found in individuals with $\mathrm{CoV}$ infection. Neurological manifestations of $\mathrm{CoV}$ have often been neglected; however, recent studies have reported neurological consequences of $\mathrm{CoV}$ infection. Here, we review these literatures and discuss the neurologic impact of $\mathrm{CoV}$ while highlighting potential implications of the novel SARS-CoV-2 in the nervous system. We also discuss the possible routes by which these viruses invade the nervous system and the mechanism by which they may induce neurological damage.
\end{abstract}

Keywords Coronavirus $\cdot$ COVID-19 $\cdot$ SARS $\cdot$ Brain $\cdot$ Neurologic

\section{Introduction}

At a glance, the coronaviruses $(\mathrm{CoV})$ are viruses that are known to cause respiratory, enteric, hepatic and neurologic diseases that may be mild or severe [1]. The coronaviruses are enveloped, positive sense viruses with $30-\mathrm{kb}$ single-stranded polyadenylated RNA that bears five genes that code for structural proteins (S, E, $\mathrm{M}, \mathrm{N}, \mathrm{HE}$ ), as well as other non-structural proteins encoding genes. These structural proteins include the spike (S) protein that enables the virus to recognize the right cellular receptor where it infects the susceptible cell. The spike protein is also responsible for the corona shape of the virus. The envelope (E) protein assembles the virion and ensures the optimum curvature of the viral envelope. The membrane $(\mathrm{M})$ protein aids in the formation of the corona shape of the virus, as well as maintains the structure of the virion through its interaction with all the other structural proteins. The nucleocapsid $(\mathrm{N})$ protein is responsible for encapsulating the viral genome in a helical nucleocapsid inside the viral particle. Lastly, the haemagglutinin esterase (HE) protein, similar to the $\mathrm{S}$ protein, plays a role in haemagglutination. It functions as acetyl-

Omamuyovwi M. Ijomone ijomoneom@ futa.edu.ng

1 The Neuro-Lab, School of Health and Health Technology, Federal University of Technology, Akure, Nigeria

2 Department of Human Anatomy, School of Health and Health Technology, Federal University of Technology, Akure, Nigeria esterase, which aids in the release of the viral particles from the infected cell occurring during the end of the replication cycle in $\beta$-coronaviruses [2]. The coronaviruses are known to be capable of rapid mutation and recombination $[1,3,4]$. The coronaviruses belong to the family Coronaviridae in the order Nidovirales. Members of this family include the pathogenic human coronaviruses (HCoV) such as $\mathrm{HCoV}-229 \mathrm{E}, \mathrm{HCoV}-\mathrm{OC} 43$, HCoV-HKU1 and HCoV-NL63 and the more commonly known severe acute respiratory syndrome coronavirus (SARS-CoV) and Middle East respiratory syndrome coronavirus (MERS-CoV) [5]. The currently named SARS-CoV-2 (by the International Committee on Taxonomy of Viruses) [6], commonly known as the novel coronavirus disease 2019 (COVID-19), is a newly discovered member of the $\mathrm{CoV}$ (considered highly pathogenic) that resembles the SARS-CoV in that they elicit similar symptoms and share similar receptor, the angiotensin-converting enzyme 2 (ACE-2), thus the reason for its name [7, 8].

The recent outbreak of the novel SARS-CoV-2 currently classed as a pandemic by the World Health Organization (WHO) has resulted in dire public health and economic crisis across the globe. According to data available on the WHO website, as of 17 April 2020, COVID-19 has currently infected over 2 million people worldwide, and the numbers continue to rise. There are well over 130 thousand confirm deaths globally, with more than 200 countries affected. The prominent clinical features presented by the SARS-CoV-2 include common symptoms like fever and dry cough usually occurring especially at the onset of the disease $[5,9,10]$. The 
subsequent characteristic symptoms presented in patients are respiratory distress syndrome (dyspnoea), myalgia, anorexia, diarrhoea, pharyngalgia, abdominal pain and fatigue [11]. Though human CoV are mostly known to cause respiratory diseases, there have been concerns of both direct and indirect neurological consequences $[2,12,13]$; however, this has often been neglected. Furthermore, a new study by Mao and colleagues highlighted characteristic clinical neurological signs presented by patients infected by the novel SARS-CoV-2 [14]. Therefore, this review aims to demonstrate, from recent evidence, the possible neurological impact of the coronaviruses on the CNS, while highlighting neurologic implications for the novel SARS-CoV-2.

\section{General mechanism of coronavirus pathogenesis}

The human coronaviruses are known major pathogens of respiratory diseases that are highly infectious and communicable. For instance, the SARS-CoV can be transmitted directly from civets to humans; the MERS-CoV can be transmitted from dromedary camels to human. There is also evidence of human to human transmission. As earlier stated, SARS-CoV2 possesses certain similar characteristics as SARS-CoV. When an individual comes in contact with a SARS-CoV-2, the virus targets major routes where it can easily propagate to get to target cells and mediate infection. Coronaviruses are respiratory viruses; thus, their first major target is the epithelial cells of the respiratory tract where they bind to receptors (the ACE-2) [12]. By binding to the ACE-2 expressed on the respiratory epithelial cells, the SARS-CoV/SARS-CoV-2 not only mediates infection but also facilitates their replication and transmission $[2,12,15,16]$. This marks the genesis of the pathology of the virus.

Typically, the expression of ACE-2 is known to play an important role in protecting the lungs against acute lung failure. However, it opens a portal through which SARS-CoV-2 could gain entry into the body. Once the disease process has been initiated, ACE-2 expression is downregulated [17]. ACE-2 is richly expressed in the epithelial cells of the respiratory tract, and it serves as a receptor for SARS-CoV, which could potentiate lung injury [18]. A recent study by Zhao and colleagues proposed that ACE-2 also serves as the receptor for the novel SARS-CoV-2 [7]. Although, unlike SARS-CoV, the novel SARS-CoV-2 binds weakly to ACE-2, but its binding strength is still greater than the threshold required for virus infection [19, 20]. ACE-2 is expressed in type 1 alveoli cells, type 2 alveoli cells, respiratory tract epithelial cells, fibroblast, endothelial cells and macrophages of the lung. But type 2 alveoli cells have the highest ACE-2 expression compared with any other human lung cells. The quantification of the expression of ACE-2 expression was determined using a single-cell RNA sequencing technology [7]. Zhao and colleagues went further to perform a gene ontology enrichment analysis to delineate the specific population of type 2 alveoli cells that express ACE-2 and study the biological processes going on in these special cell population in comparison with other non-ACE-2 expressing type 2 alveoli cells. It was found that the ACE- 2 type 2 alveoli cells possess multiple viral process-related genes involved in positive regulation of viral genome replication, virion assembly and viral life cycle. This implies that the novel SARS-CoV-2 can take advantage of the special population ACE-2 expressing type 2 alveoli cells for its replication and transmission [7]. It is noteworthy that expression of ACE-2 is not limited to the lungs only, but there is also abundant expression of ACE-2 on the endothelial cells, enterocytes, renal cells, hepatocytes, smooth muscles, nerve cells and apparently every organ in the body. For instance, ACE-2 is widely distributed and expressed in the enterocytes, where it typically serves as a co-receptor for the uptake of amino acid from food nutrient $[16,21]$. Thus, it implies that entry of SARS-CoV/SARS-CoV-2 into the circulation can easily result into the widespread of these viruses around the body [22]. Thus, from the circulation, these coronaviruses can travel to infect the endothelial cells of the blood-brain barrier $[2]$.

\section{Potential mechanism of SARS-CoV-2 infection}

With its S protein, when the SARS-CoV (or SARS-CoV-2 as the case may be) binds to the ACE-2, it will result in the downregulation of ACE-2 expression as well as mediating the entry and replication of the virus. Note that SARS-CoV2 cannot downregulate the expression of ACE. Typically, in the renin-angiotensin system, ACE binds on its substrate, the decapeptide angiotensin 1 (Ang 1), cleaving it to yield a product, octapeptide angiotensin II (Ang II). The accumulation of Ang II is known to mediate severe lung injury by acting on angiotensin II type 1a ( $\left.\mathrm{AT}_{1 \mathrm{a}}\right)$ receptors. Interestingly, in this ideal situation, ACE-2 plays a protective role by cleaving Ang II to yield angiotensin 1-7. It also cleaves Ang I to generate angiotensin 1-9. The novel SARS-CoV-2 potentiates infection by binding on the ACE-2, thereby downregulating their expression. This loss of ACE- 2 expression, therefore, elicits the dysregulation of the renin-angiotensin system, which causes an elevated production of angiotensin II (Ang II) that acts on both angiotensin II type $1 \mathrm{a}\left(\mathrm{AT}_{1 \mathrm{a}}\right)$ and angiotensin II type $2\left(\mathrm{AT}_{2}\right)$ receptors. The action of $\mathrm{Ang} \mathrm{II}$ on $\mathrm{AT}_{2}$ receptors inhibits their expression, whereas its action on $\mathrm{AT}_{1 \mathrm{a}}$ receptors activates them. It has also been shown that the reduction in $\mathrm{AT}_{2}$ expression exacerbates acute lung injury. On the other hand, the activation of $\mathrm{AT}_{1 \mathrm{a}}$ receptor will also mediate Ang II-induced vascular permeability and severe acute lung injury. Taken together, the consequential reduction in ACE-2 expression and the increased production of Ang II correlates to 
severe acute lung injury $[18,23]$. Also facilitating the entry and transmission of the SARS-CoV-2, via its interaction with ACE-2, is priming of the virus' $S$ protein by transmembrane protease serine 2 (TMPRSS2) gene [24]. This pathologic mechanism is illustrated in Fig. 1.

\section{Neuroinvasion of coronavirus: mechanisms by which it infiltrates the nervous system}

Although $\mathrm{CoV}$ are primarily considered to be localized in the respiratory tract, they have also been detected in the brains of infected individuals. Several techniques, such as immunohistochemistry, electron microscopy and real-time reverse transcription-PCR have been used to detect $\mathrm{CoV}$ presence in the brain $[25,26]$. This has led several authors to focus their research on identifying the possible routes by which this virus invades the CNS. Several studies have postulated the olfactory-haematogenous pathway (Fig. 2), trans-neuronal machinery (Fig. 3) and lymphatic pathway, as putative routes of coronavirus entry into the CNS $[12,26]$.

The olfactory tract has been implicated as a major route through which toxicants reaches the CNS. It is then of no surprise that it has been implicated as a possible route for $\mathrm{HCoV}$ invasion into the CNS, and this is likely to include the SARS-CoV-2. Several authors like McCray et al. [27], Butler et al. [28] and Netland et al. [26] have reported that after an intranasal infection, both HCoV-OC43 and SARS-

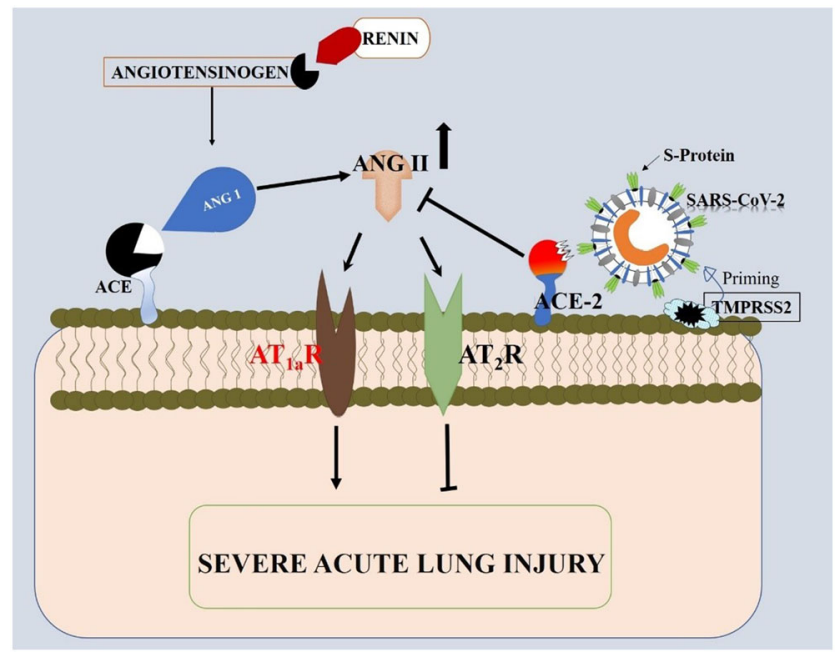

Fig. 1 Illustration of the mechanism by which SARS-CoV-2 mediates pathology. SARS-CoV-2 mediates pathology by interacting with ACE-2 thereby inhibiting its function on ANG II. The accumulation of ANG II results in a cascade of interactions that consequently leads to severe acute lung injury. ACE, angiotensin-converting enzyme; ACE-2, angiotensinconverting enzyme 2; ANG I, angiotensin I; ANG II, angiotensin II; SARS-CoV-2, severe acute respiratory syndrome coronavirus 2 ; $\mathrm{S}$ protein, spike protein; TMPRSS2, transmembrane protease serine 2 gene; AT1aR, angiotensin II type 1a receptor; AT2R, angiotensin II type 2 receptor

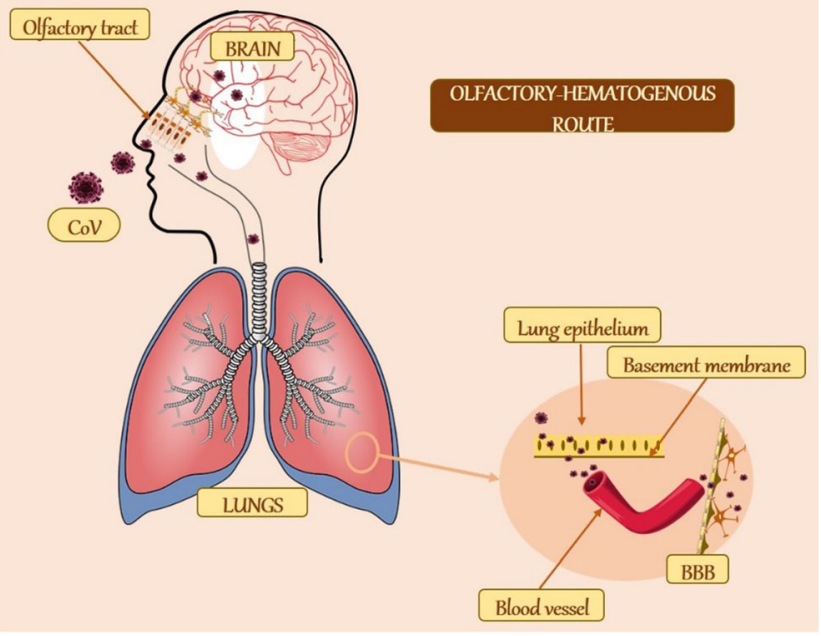

Fig. 2 Schematic representation of the olfactory-haematogenous route of $\mathrm{CoV}$ neuroinvasion. $\mathrm{CoV}$ may gain access to the brain through the olfactory tract or via the lung epithelium. In the lungs, it is typically localized at the apical surface of epithelial cells. However, it sometimes infects the basolateral regions. From these areas, it crosses the basement membrane to reach the blood vessel. These vessels then transport it across the $\mathrm{BBB}$ into the brain. $\mathrm{CoV}$, coronavirus; $\mathrm{BBB}$, blood-brain barrier

$\mathrm{CoV}$ which are very similar to SARS-CoV-2 were shown to infect the respiratory tract in mice and to be neuroinvasive. Numerous data over the years have shown that several strains of $\mathrm{CoV}$ such as neurotropic MHV, SARS-CoV34 or MERS$\mathrm{CoV}$, and $\mathrm{HCoV}-\mathrm{OC} 43$ are certainly neuroinvasive in both mice and humans [28-31]. Additionally, early steps of subsequent neuropropagation within the CNS in susceptible mice

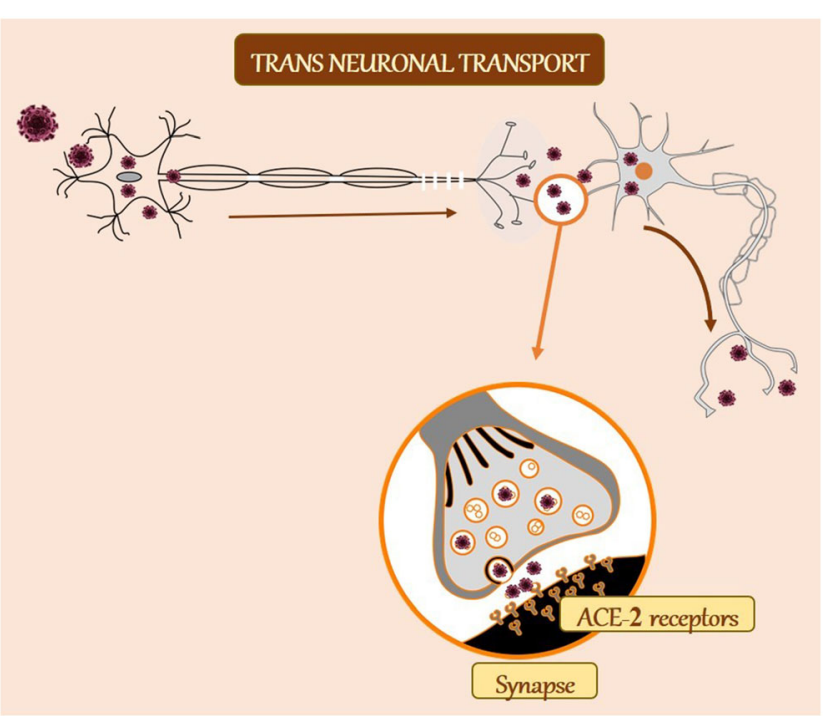

Fig. 3 Trans-neuronal machinery as a possible mechanism of $\mathrm{CoV}$ neuroinvasion. In the trans-neuronal route, the virus infects a peripheral neuron and by retrograde transport and infects another neuron via synapse. The virus is released by the process of exocytosis in the presynaptic terminal. It then binds to ACE-2 receptors on the postsynaptic neuron and taken up via receptor-mediated endocytosis. ACE-2, angiotensinconverting enzyme 2 
have been delineated, as well as in humans [31]. Upon reaching the respiratory airways, $\mathrm{HCoV}$ could cross the basolateral surfaces of epithelial cells [32] into the blood circulation and spread to other tissues including the CNS $[33,34]$ (Fig. 2). Although $\mathrm{HCoV}$ are mostly limited to the respiratory airways, the ability of these viruses to spread to other tissues, including the CNS has been severally documented [13, 35]. In the circulation, a virus will infect either endothelial cells of the blood-brain barrier (BBB) or epithelial cells of the bloodcerebrospinal fluid barrier (BCSFB) in the choroid plexus (CP) located in the ventricles of the brain, or leukocytes that will serve as a vector for dissemination towards the CNS [34]. Therefore, it is possible that the novel SARS-CoV-2 could also be neuroinvasive via haematogenous respiratory pathways (Fig. 2). Furthermore, a case could also be made for direct $\mathrm{HCoV}$ neuroinvasion through olfactory receptors, as other neurotropic viruses including, influenza, herpes simplex and poliovirus have been observed to migrate along axons of olfactory receptor neurons (of olfactory epithelium) into the CNS [36, 37] (Fig. 2).

The trans-neuronal retrograde machinery has also been identified as a potential route. Here, the $\mathrm{HCoV}$ virus infects peripheral neurons to invade the CNS via the axonal retrograde transport $[13,38]$. Increasing evidence demonstrates the ability of $\mathrm{CoV}$ to first invade peripheral nerve terminals and then, via synapses, gain access to the CNS [39-41]. The trans-synaptic transfer has been well documented for other $\mathrm{CoV}$, such as HEV679-10 [42]. HEV 67N are the first $\mathrm{CoV}$ found to invade the porcine brain, and it shares more than $91 \%$ homology with the novel SARS-CoV-2 [43, 44]. In susceptible mice, HCoVOC43 showed a selective tropism for neurons in which it is able to use axonal transport as a way of neuron-to-neuron propagation [31], further proving the neuronal transgenic retrograde machinery as a possible mechanism of $\mathrm{CoV}$ (including SARS-CoV-2) neuroinvasion (Fig. 3).

The lymphatic system has also been implicated as a possible route of $\mathrm{CoV}$ neuroinvasion. Although the exact mechanism is not known, different strains of CoV, including SARS$\mathrm{CoV}$, have the ability to infect cells involved in intrinsic immunity. Through these cells, they are able to spread to several tissues, including the CNS [45]. This is consistent with findings in mice where the murine counterpart of $\mathrm{HCoV}$, the neurotropic mouse hepatitis virus (MHV), invaded the CNS through the lymphatic systems [46]. Thus, accumulating evidence suggest that these viruses, first isolated as pathogens of the respiratory tract might be neurotropic, neuroinvasive and neurovirulent.

\section{Neurologic impact of coronaviruses}

As reviewed in the previous section, while SARS-CoV2 is considered a respiratory pathogen [27], it has also been localized in the brains of infected patients [34, 42], suggesting its ability to impact normal neurologic structures and functions. Table 1 summarizes neurological symptoms that have been reported in $\mathrm{CoV}$ infection.

\section{Neurological symptoms associated with coronavirus}

\section{CNS symptoms}

The neurovirulent property of $\mathrm{CoV}$ has led to the development of several CNS-related neurological disorders and symptoms. Multiple sclerosis (MS), a disease of CNS characterized by demyelination, is one of these disorders and has been repetitively associated with the $\mathrm{CoV}$ neuro-infection. Although several viral infections have been associated as one of the aetiologies of this disease, numerous authors were able to detect the presence of $\mathrm{CoV}$ in the brain of MS patients proving its involvement in the pathogenesis MS. Interestingly, upper respiratory infections of viral origin were shown to be an important trigger of MS attacks. Apart from human studies, several works on animal models have associated MHV (the murine counterpart of $\mathrm{HCoV}$ ) with MS [46]. Other disorders of the CNS linked to $\mathrm{CoV}$ infection are meningitis and encephalitis $[47,50]$. Li et al. [48] conducted a study on clinically diagnosed acute encephalopathy patients with $\mathrm{CoV}$ infection. They reported that these patients experienced neurological symptoms such as headache, convulsion and altered levels of consciousness. During the recent SARS-CoV-2 outbreak, also known as COVID-19, several doctors have reported neurological symptoms like strokes, seizures, encephalitis-like symptoms and acroparesthesia in COVID-19 patients. They also reported that these patients suffering with encephalopathy are usually confused and lethargic $[14,49]$.

\section{PNS symptoms}

As proposed by the neuronal transgenic retrograde machinery, $\mathrm{HCoV}$ infects peripheral neurons to invade the CNS via the axonal transport machinery $[13,38]$. This is accompanied by increasing evidence that show that $\mathrm{CoV}$ may first invade peripheral nerve terminals and then gain access to the CNS via a synapse-connected route [39-41]. The neurotropic and neuroinvasive potential of the $\mathrm{HCoV}$ in the PNS has led several authors to investigate the possible neurovirulent potential of SARS-CoV-2 in the PNS. A recent report showed that patients with SARS-CoV2 infection exhibited neurological syndromes such as a diminished sense of smell and taste and loss of speaking ability [49]. Several reports have associated acute flaccid paralysis [50], entrapment neuropathy [51] and other neurological symptoms, including Guillain-Barré syndrome [52], with CoV infections. 
Table 1 Summary of neurologic impact of $\mathrm{CoV}$

\begin{tabular}{|c|c|c|c|}
\hline $\mathrm{S} / \mathrm{N}$ & Neurological symptoms & Implications & References \\
\hline \multirow[t]{7}{*}{1} & \multirow[t]{7}{*}{ CNS symptoms } & Multiple sclerosis & {$[46]$} \\
\hline & & Meningitis & {$[47]$} \\
\hline & & Encephalitis & {$[48]$} \\
\hline & & Headache & {$[48]$} \\
\hline & & Convulsion & {$[48]$} \\
\hline & & Stroke & [49] \\
\hline & & Seizure & [49] \\
\hline \multirow[t]{5}{*}{2} & \multirow[t]{5}{*}{ PNS symptoms } & Flaccid paralysis & {$[50]$} \\
\hline & & Diminished sense of smell, taste & [49] \\
\hline & & Entrapment neuropathy & {$[51]$} \\
\hline & & Loss of speaking ability & [49] \\
\hline & & Guillain-Barré syndrome & {$[52]$} \\
\hline \multirow[t]{4}{*}{3} & \multirow[t]{4}{*}{ Muscular symptoms } & Acute quadriplegic myopathy & {$[53]$} \\
\hline & & Thick filament myopathy & {$[53]$} \\
\hline & & Necrotizing myopathy & [53] \\
\hline & & Myalgia & {$[48]$} \\
\hline \multirow[t]{4}{*}{4} & \multirow[t]{4}{*}{ Cognitive impairment } & Attention and memory deficit & {$[54,55]$} \\
\hline & & Impaired visual-spatial abilities & {$[56,57]$} \\
\hline & & Impaired learning & {$[55]$} \\
\hline & & Auditory and visual hallucinations & {$[58]$} \\
\hline \multirow[t]{3}{*}{5} & \multirow[t]{3}{*}{ Mood-altering behaviour } & Depression & {$[55,59]$} \\
\hline & & Anxiety & {$[55,60]$} \\
\hline & & Abnormal behaviour or speech & [47] \\
\hline
\end{tabular}

\section{Muscular symptoms}

Several muscular disorders have been observed in CoVinfected patients. These disorders include critical illness myopathy (CIM), acute quadriplegic myopathy, thick filament myopathy and necrotizing myopathy [53]. CIM is typically a non-necrotizing diffuse myopathy with associated fatty degeneration of muscle fibres, fibre atrophy and fibrosis and it may represent an antecedent to acute necrotizing myopathy. This is distinguished by extensive myonecrosis with vacuolization and phagocytosis of muscle fibres and is linked to multiple organ dysfunction [61]. However, these functional disabilities in muscles could be a result of intensive care unitacquired muscle loss and weakness and not a result of the infection $[62,63]$.

\section{Behavioural deficits implicated in CoV infections}

\section{Cognitive impairment}

$\mathrm{CoV}$ infection has been associated with several impaired cognitive functions. They include attention and memory deficits [54], impaired visual-spatial abilities, declarative memory and executive function [57]. In a study conducted by Jacomy et al. [55], they observed a reduced size in the hippocampus in mice following $\mathrm{HCoV}$ infection, which they inferred could trigger deficits in higher neurological functions such as learning and memory. This finding is supported by a growing number of human studies showing sudden changes in memory, learning and attention preceded by the release of cytokines [55]. Cytokine release has been connected with $\mathrm{CoV}$ infection [64]. Furthermore, a single-centre cohort study in acute respiratory distress syndrome (ARDS) survivors found that a longer duration of hypoxemia - a characteristic symptom of SARS-CoV-2 [49] — was associated with cognitive impairment [65]. Hypoxia has been linked to brain atrophy, lateral ventricle enlargement and concomitant impairments in memory [61].

\section{Mood-altering behavioural impairment}

Alterations in mood have been noticed in patients with ARDS. These mood-altering disturbances include depression and non-specific anxiety phenomena [60, 66]. In an instance, Schelling and Kapfhammer [67] noted that patients who survived ARDS often had substantial 
residual angst, with vivid and distorted frightening memories of what they had experienced even after their acute brain dysfunction had resolved. Adhikari et al. [68] and Bienvenu et al. [69] also reported the incidence of depression and non-specific anxiety in patients with respiratory disorders. Characteristic symptoms such as altered mental status, personality change, abnormal behaviour or speech, and movement disorders have been associated with $\mathrm{CoV}$-induced encephalopathy infection [47]. In a behavioural study conducted by Jacomy et al. [55], CoV-infected mice exhibited decreased activity in an open field test. In the same study, the mice exhibited decreased locomotor activity, exploration pattern, sniffing and sifting in the open field test, all indicating depression and anxiety [55]. This is consistent with the study by Severance et al. [59] where $\mathrm{CoV}$ infection was associated with psychologic disorders, for instance, bipolar disorder and depression in patients.

\section{Brain regions imparted by $\mathrm{CoV}$ neuroinvasion}

The ability of $\mathrm{CoV}$ to invade the brain and cause alteration in brain structures have been reported in several studies. Following neuroinvasion, these viruses accumulate in different brain regions such as the dorsal vagal complex (solitary nucleus, area postrema and dorsal motor nucleus of the vagus), which is critical for cardiorespiratory function, as well as the basal ganglia, piriform and infralimbic region of the cortex, and the dorsal raphe of the midbrain. Therefore, it can be implied that the sudden and severe symptoms occurring in $\mathrm{CoV}$ infection (including SARS-CoV2) may result from subsequent functional impairment of these critical brain regions [26]. $\mathrm{HCoV}$ including SARS-CoV and MERS-CoV have been heavily detected in the brainstem, specifically in the solitary nucleus and nucleus ambiguous. Chemoreceptors and mechanoreceptors in lungs and respiratory tract sends sensory information to the solitary nucleus, while nerve supply to blood vessels, airway smooth muscle and glands are efferent fibres derived from the solitary nucleus and the nucleus ambiguous [42]. These connections indicate that respiratory distress experienced during SAR-CoV2 infection may be due to malfunction of the brainstem's cardiorespiratory centre $[42,48]$. Li et al. [48] used magnetic resonance imaging (MRI) to perform some imaging diagnostics on patients with $\mathrm{CoV}$-induced encephalopathy. They observed some abnormality in the temporal lobe, the periventricular region, basal ganglia and the thalamus. Netland et al. [26] also observed infection and structural alteration in the cardiorespiratory centre in the medulla of SARS-CoV-induced mice. Additionally, Jacomy et al. [55] demonstrated that mice that survived from $\mathrm{CoV}$-induced acute encephalitis exhibited a reduced hippocampus.

\section{Potential mechanism of CoV-induced neuronal death}

Several reports on neuronal cell death following $\mathrm{CoV}$ infection have been documented $[55,64,70]$. On entry into the neuroplasm via the ACE-2 receptors, $\mathrm{CoV}$ induces neuronal death through apoptosis (Fig. 4), necrosis and in rare cases and autophagy [16, 55]. Xu et al. [64] microscopically examined SAR-CoV-infected brain and revealed neuron necrosis. Jacomy et al. [55] postulated apoptosis as the mechanism involved in neuronal loss observed in CA1 and CA3 layers of the hippocampus in $\mathrm{CoV}$-induced acute encephalitis mice. They were able to support their finding by demonstrating the immunopresence of caspase- 3 along with nuclear fragmentation in cultured cortical and hippocampal neurons. Caspases are the principal executors of apoptotic cell death, and caspase-3 has been severally identified as a key mediator of the apoptotic process in mammalian cells, including neurons $[55,71]$. Chen and Lane [72] reported apoptosis as a mechanism by which the MHV (the murine analogue of $\mathrm{HCoV}$ ) induced neuronal death in mice brain.

Additionally, an excessive and possibly dysregulated cytokine response has been implicated in neuronal death in patients with SARS [70,73]. Lending support to this hypothesis, three cytokines often associated with immunopathology, IL-1, tumour necrosis factor alpha and IL-6 [26], are all upregulated in the brains of CoV-infected mice [27]. Although the exact mechanism by which SARS-CoV infection induces production of IL-6 in neurons is unknown, SARS-CoV products, such as the $\mathrm{N}$ protein, may directly induce IL-6 [74]. Alternatively, IL-6 production may be a normal consequence of a highly productive neuronal infection or may be induced

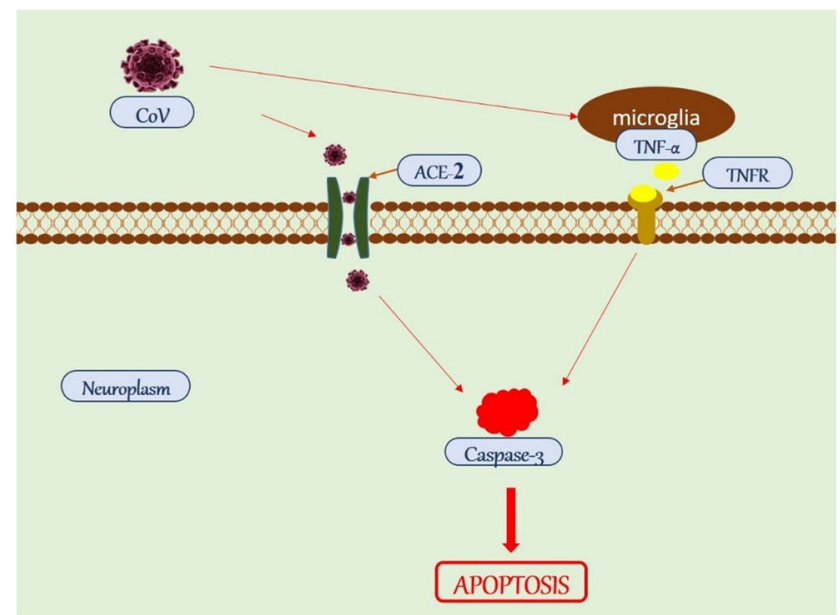

Fig. 4 Possible mechanism of $\mathrm{CoV}$-induced neuronal death. $\mathrm{CoV}$ can either activate the productions of cytokines (TNF- $\alpha$ ) or gain entry into the neuroplasm via ACE-2 receptor through receptor-mediated endocytosis. Both pathways lead to the activation of effector caspases (caspase-3), which induces cell death via apoptosis. CoV, coronavirus; ACE-2, angiotensin-converting enzyme 2 ; TNF- $\alpha$, tumour necrosis factor alpha; TNFR, tumour necrosis factor alpha receptor 
by another inflammatory mediator, such as IL-1 or tumour necrosis factor alpha [26] also released in the CNS infected with SARS-CoV [27]. A high level of IL-6 leads to progressive neurological disorders with neurodegeneration, and subsequently cognitive decline [48]. Xu et al. [64] described a patient who developed progressive neurological symptoms starting at day 28 after onset. Autopsy of the patient's brain showed the presence of SARS-CoV and some pathological signs of neuronal necrosis [64]. Netland et al. [26] suggested autophagy as a non-inflammatory mechanism by which SARS-CoV induces neuronal loss in SARS-CoV-infected K18-hACE2 mice.

\section{Concluding remarks}

Coronaviruses are neuroinvasive and neurotropic, with potential neuropathological consequences in vulnerable populations. Although it is widely accepted that human coronaviruses such as MERS-CoV, SARS-CoV and the novel SARS-CoV-2 are usually confined to the respiratory tract, and mostly result in respiratory diseases, this review has highlighted studies to demonstrate neuroinvasive potential and potential neurological consequences of human coronaviruses. This review also discusses the behavioural and structural alterations brought about by the coronavirus neuro-infection, while also highlighting the possible mechanisms by which these viruses may induce neuronal death. Most studies reviewed here have focused on previously identified coronaviruses; however, given the similarity between the novel SARS-CoV-2 and earlier coronaviruses, this review demonstrates strong neurological implications for the novel virus. Therefore, understanding the underpinning mechanisms of neuroinvasion and interaction of coronaviruses, especially SARS-CoV-2 with the nervous system is essential to evaluate potentially pathological consequences and to design novel diagnostic and intervention strategies.

Acknowledgements OMI acknowledges the support of International Brain Organization (IBRO) to The Neuro-Lab, Federal University of Technology Akure, Nigeria.

Author contributions Conception-OMI; Design-JDI, OMI; Manuscript writing-JDI, CWI, OMI. All authors approved the final manuscript draft.

\section{Compliance with ethical standards}

Conflict of interest The authors declare that they have no conflict of interest.

Ethical approval None.

\section{References}

1. Kahn JS, McIntosh K (2005) History and recent advances in coronavirus discovery. Pediatr Infect Dis J 24(11):S223-S227

2. Desforges M, Favreau DJ, Brison É, Desjardins J, Meessen-Pinard M, Jacomy H, Talbot PJ (2013) Human coronaviruses: respiratory pathogens revisited as infectious neuroinvasive, neurotropic, and neurovirulent agents. In: Singh SK, Ruzek D (eds) Neuroviral Infections. CRC Press, Boca Raton, pp 93-121. https://doi.org/10. 1201/9780429173868

3. Woo PC, Lau SK, C-m C, K-h C, H-w T, Huang Y, Wong BH, Poon RW, Cai JJ, W-k L (2005) Characterization and complete genome sequence of a novel coronavirus, coronavirus HKU1, from patients with pneumonia. J Virol 79(2):884-895

4. Woo PC, Lau SK, Lam CS, Lau CC, Tsang AK, Lau JH, Bai R, Teng JL, Tsang CC, Wang M (2012) Discovery of seven novel Mammalian and avian coronaviruses in the genus deltacoronavirus supports bat coronaviruses as the gene source of alphacoronavirus and betacoronavirus and avian coronaviruses as the gene source of gammacoronavirus and deltacoronavirus. J Virol 86(7):3995-4008

5. Huang C, Wang Y, Li X, Ren L, Zhao J, Hu Y, Zhang L, Fan G, Xu J, Gu X (2020) Clinical features of patients infected with 2019 novel coronavirus in Wuhan, China. Lancet 395(10223):497-506

6. Zhang JJ, Dong X, Cao YY, Yuan YD, Yang YB, Yan YQ, Akdis CA, Gao YD (2020) Clinical characteristics of 140 patients infected by SARS-CoV-2 in Wuhan, China. Allergy. https://doi.org/10. 1111/all.14238

7. Zhao Y, Zhao Z, Wang Y, Zhou Y, Ma Y, Zuo W (2020) Single-cell RNA expression profiling of ACE2, the putative receptor of Wuhan 2019-nCov. BioRxiv. https://doi.org/10.1101/2020.01.26.919985

8. Zhou P, Yang X-L, Wang X-G, Hu B, Zhang L, Zhang W, Si H-R, Zhu Y, Li B, Huang C-L (2020) Discovery of a novel coronavirus associated with the recent pneumonia outbreak in humans and its potential bat origin. BioRxiv. https://doi.org/10.1101/2020.01.22. 914952

9. Wang D, Hu B, Hu C, Zhu F, Liu X, Zhang J, Wang B, Xiang H, Cheng Z, Xiong Y (2020) Clinical characteristics of 138 hospitalized patients with 2019 novel coronavirus-infected pneumonia in Wuhan, China. JAMA 323(11):1061-1069

10. Khan S, Ali A, Siddique R, Nabi G (2020) Novel coronavirus is putting the whole world on alert. J Hosp Infect 104(3):252-253

11. Guan WJ, Ni ZY, Hu Y et al (2020) Clinical characteristics of coronavirus disease 2019 in China. New Eng J Med 382(18): $1708-1720$

12. Desforges M, Le Coupanec A, Dubeau P, Bourgouin A, Lajoie L, Dubé M, Talbot PJ (2020) Human coronaviruses and other respiratory viruses: underestimated opportunistic pathogens of the central nervous system? Viruses 12(1):14

13. Desforges M, Le Coupanec A, Stodola JK, Meessen-Pinard M, Talbot PJ (2014) Human coronaviruses: viral and cellular factors involved in neuroinvasiveness and neuropathogenesis. Virus Res 194:145-158

14. Mao L, Wang M, Chen S, He Q, Chang J, Hong C, Zhou Y, Wang D, Miao X, Hu Y (2020) Neurological manifestations of hospitalized patients with COVID-19 in Wuhan, China: a retrospective case series study. medRxiv. https://doi.org/10.1101/2020.02.22. 20026500

15. Ding Y, Wang H, Shen H, Li Z, Geng J, Han H, Cai J, Li X, Kang W, Weng D (2003) The clinical pathology of severe acute respiratory syndrome (SARS): a report from China. J Pathol 200(3):282289

16. Hamming I, Timens W, Bulthuis M, Lely A, Navis G, van Goor H (2004) Tissue distribution of ACE2 protein, the functional receptor for SARS coronavirus. A first step in understanding SARS pathogenesis. J Pathol 203(2):631-637 
17. Kuba K, Imai Y, Rao S, Jiang C, Penninger JM (2006) Lessons from SARS: control of acute lung failure by the SARS receptor ACE2. J Mol Med 84(10):814-820

18. Kuba K, Imai Y, Rao S, Gao H, Guo F, Guan B, Huan Y, Yang P, Zhang Y, Deng W (2005) A crucial role of angiotensin converting enzyme 2 (ACE2) in SARS coronavirus-induced lung injury. Nat Med 11(8):875-879

19. Li W, Sui J, Huang I-C, Kuhn JH, Radoshitzky SR, Marasco WA, Choe H, Farzan M (2007) The S proteins of human coronavirus NL63 and severe acute respiratory syndrome coronavirus bind overlapping regions of ACE2. Virology 367(2):367-374

20. He L, Ding Y, Zhang Q, Che X, He Y, Shen H, Wang H, Li Z, Zhao L, Geng J (2006) Expression of elevated levels of pro-inflammatory cytokines in SARS-CoV-infected ACE2+ cells in SARS patients: relation to the acute lung injury and pathogenesis of SARS. J Pathol 210(3):288-297

21. Hashimoto T, Perlot T, Rehman A, Trichereau J, Ishiguro H, Paolino M, Sigl V, Hanada T, Hanada R, Lipinski S (2012) ACE2 links amino acid malnutrition to microbial ecology and intestinal inflammation. Nature 487(7408):477-481

22. To K, Tong JH, Chan PK, Au FW, Chim SS, Allen Chan K, Cheung JL, Liu EY, Tse GM, Lo AW (2004) Tissue and cellular tropism of the coronavirus associated with severe acute respiratory syndrome: an in-situ hybridization study of fatal cases. J Pathol 202(2):157163

23. Imai Y, Kuba K, Rao S, Huan Y, Guo F, Guan B, Yang P, Sarao R, Wada T, Leong-Poi H (2005) Angiotensin-converting enzyme 2 protects from severe acute lung failure. Nature 436(7047):112-116

24. Hoffmann M, Kleine-Weber H, Krüger N, Mueller MA, Drosten C, Pöhlmann S (2020) The novel coronavirus 2019 (2019-nCoV) uses the SARS-coronavirus receptor ACE2 and the cellular protease TMPRSS2 for entry into target cells. BioRxiv. https://doi.org/10. $1101 / 2020.01 .31 .929042$

25. Gu J, Gong E, Zhang B, Zheng J, Gao Z, Zhong Y, Zou W, Zhan J, Wang S, Xie Z (2005) Multiple organ infection and the pathogenesis of SARS. J Exp Med 202(3):415-424

26. Netland J, Meyerholz DK, Moore S, Cassell M, Perlman S (2008) Severe acute respiratory syndrome coronavirus infection causes neuronal death in the absence of encephalitis in mice transgenic for human ACE2. J Virol 82(15):7264-7275

27. McCray PB, Pewe L, Wohlford-Lenane C, Hickey M, Manzel L, Shi L, Netland J, Jia HP, Halabi C, Sigmund CD (2007) Lethal infection of K18-hACE2 mice infected with severe acute respiratory syndrome coronavirus. J Virol 81(2):813-821

28. Butler N, Pewe L, Trandem K, Perlman S (2006) Murine encephalitis caused by $\mathrm{HCoV}-\mathrm{OC} 43$, a human coronavirus with broad species specificity, is partly immune-mediated. Virology 347(2): 410-421

29. Morfopoulou S, Brown JR, Davies EG, Anderson G, Virasami A, Qasim W, Chong WK, Hubank M, Plagnol V, Desforges M (2016) Human coronavirus OC43 associated with fatal encephalitis. N Engl J Med 375(5):497-498

30. Li K, Wohlford-Lenane C, Perlman S, Zhao J, Jewell AK, Reznikov LR, Gibson-Corley KN, Meyerholz DK, McCray PB Jr (2016) Middle East respiratory syndrome coronavirus causes multiple organ damage and lethal disease in mice transgenic for human dipeptidyl peptidase 4. J Infect Dis 213(5):712-722

31. Dubé M, Le Coupanec A, Wong AH, Rini JM, Desforges M, Talbot PJ (2018) Axonal transport enables neuron-to-neuron propagation of human coronavirus OC43. J Virol 92(17):e00404-e00418

32. Dijkman R, Jebbink MF, Koekkoek SM, Deijs M, Jónsdóttir HR, Molenkamp R, Ieven M, Goossens H, Thiel V, van der Hoek L (2013) Isolation and characterization of current human coronavirus strains in primary human epithelial cell cultures reveal differences in target cell tropism. J Virol 87(11):6081-6090
33. Talbot PJ, Jacomy H, Desforges M (2008) Pathogenesis of human coronaviruses other than severe acute respiratory syndrome coronavirus. In: Nidoviruses. American Society of Microbiology, pp 313324

34. Desforges M, Miletti TC, Gagnon M, Talbot PJ (2007) Activation of human monocytes after infection by human coronavirus $229 \mathrm{E}$. Virus Res 130(1-2):228-240

35. Desforges M, Le Coupanec A, Brison É, Meessen-Pinard M, Talbot PJ (2014) Neuroinvasive and neurotropic human respiratory coronaviruses: potential neurovirulent agents in humans. In: Adhikari R, Thapa S (eds) Infectious Diseases and Nanomedicine I, Advances in Experimental Medicine and Biology, vol 807. Springer, New Delhi, pp 75-96. https://doi.org/10.1007/978-81322-1777-0_6

36. Durrant DM, Ghosh S, Klein RS (2016) The olfactory bulb: an immunosensory effector organ during neurotropic viral infections. ACS Chem Neurosci 7(4):464-469

37. Mori I, Nishiyama Y, Yokochi T, Kimura Y (2005) Olfactory transmission of neurotropic viruses. J Neurovirol 11(2):129-137

38. Berth SH, Leopold PL, Morfini G (2009) Virus-induced neuronal dysfunction and degeneration. Front Biosci 14:5239-5259

39. Li Y-C, Bai W-Z, Hirano N, Hayashida T, Hashikawa T (2012) Coronavirus infection of rat dorsal root ganglia: ultrastructural characterization of viral replication, transfer, and the early response of satellite cells. Virus Res 163(2):628-635

40. Li YC, Bai WZ, Hirano N, Hayashida T, Taniguchi T, Sugita Y, Tohyama K, Hashikawa T (2013) Neurotropic virus tracing suggests a membranous-coating-mediated mechanism for transsynaptic communication. J Comp Neurol 521(1):203-212

41. Matsuda K, Park C, Sunden Y, Kimura T, Ochiai K, Kida H, Umemura T (2004) The vagus nerve is one route of transneural invasion for intranasally inoculated influenza a virus in mice. Vet Pathol 41(2):101-107

42. Li YC, Bai WZ, Hashikawa T (2020) The neuroinvasive potential of SARS-CoV2 may be at least partially responsible for the respiratory failure of COVID-19 patients. J Med Virol. https://doi.org/ 10.1002/jmv. 25728

43. Li Z, He W, Lan Y, Zhao K, Lv X, Lu H, Ding N, Zhang J, Shi J, Shan C (2016) The evidence of porcine hemagglutinating encephalomyelitis virus induced nonsuppurative encephalitis as the cause of death in piglets. PeerJ 4:e2443

44. Gonzalez J, Gomez-Puertas P, Cavanagh D, Gorbalenya A, Enjuanes L (2003) A comparative sequence analysis to revise the current taxonomy of the family Coronaviridae. Arch Virol 148(11): $2207-2235$

45. Lassnig C, Sanchez CM, Egerbacher M, Walter I, Majer S, Kolbe T, Pallares P, Enjuanes L, Müller M (2005) Development of a transgenic mouse model susceptible to human coronavirus 229E. Proc Natl Acad Sci 102(23):8275-8280

46. Arbour N, Day R, Newcombe J, Talbot PJ (2000) Neuroinvasion by human respiratory coronaviruses. J Virol 74(19):8913-8921

47. Bookstaver PB, Mohorn PL, Shah A, Tesh LD, Quidley AM, Kothari R, Bland CM, Weissman S (2017) Management of viral central nervous system infections: a primer for clinicians. J Cent Nerv Syst Dis 9:1179573517703342

48. Li Y, Li H, Fan R, Wen B, Zhang J, Cao X, Wang C, Song Z, Li S, Li X (2016) Coronavirus infections in the central nervous system and respiratory tract show distinct features in hospitalized children. Intervirology 59(3):163-169

49. Rabin RC (2020) Some coronavirus patients show signs of brain ailments. The New York Times. Accessed April 2020

50. Turgay C, Emine T, Ozlem K, Muhammet SP, Haydar AT (2015) A rare cause of acute flaccid paralysis: human coronaviruses. J Pediatr Neurosci 10(3):280-281

51. Herridge MS, Cheung AM, Tansey CM, Matte-Martyn A, DiazGranados N, Al-Saidi F, Cooper AB, Guest CB, Mazer CD, Mehta 
S (2003) One-year outcomes in survivors of the acute respiratory distress syndrome. N Engl J Med 348(8):683-693

52. Sharma K, Tengsupakul S, Sanchez O, Phaltas R, Maertens P (2019) Guillain-Barré syndrome with unilateral peripheral facial and bulbar palsy in a child: a case report. SAGE Open Med Case Rep 7:2050313X19838750

53. Pandit L, Agrawal A (2006) Neuromuscular disorders in critical illness. Clin Neurol Neurosurg 108(7):621-627

54. Kapfhammer HP, Rothenhäusler HB, Krauseneck T, Stoll C, Schelling G (2004) Posttraumatic stress disorder and healthrelated quality of life in long-term survivors of acute respiratory distress syndrome. Am J Psychiatr 161(1):45-52

55. Jacomy H, Fragoso G, Almazan G, Mushynski WE, Talbot PJ (2006) Human coronavirus OC43 infection induces chronic encephalitis leading to disabilities in BALB/C mice. Virology 349(2):335-346

56. Herridge MS, Tansey CM, Matté A, Tomlinson G, Diaz-Granados N, Cooper A, Guest CB, Mazer CD, Mehta S, Stewart TE (2011) Functional disability 5 years after acute respiratory distress syndrome. N Engl J Med 364(14):1293-1304

57. Pandharipande PP, Girard TD, Jackson JC, Morandi A, Thompson JL, Pun BT, Brummel NE, Hughes CG, Vasilevskis EE, Shintani AK (2013) Long-term cognitive impairment after critical illness. N Engl J Med 369(14):1306-1316

58. Sheng B, Cheng SKW, Lau KK, Li HL, Chan ELY (2005) The effects of disease severity, use of corticosteroids and social factors on neuropsychiatric complaints in severe acute respiratory syndrome (SARS) patients at acute and convalescent phases. Eur Psychiatry 20(3):236-242

59. Severance EG, Dickerson FB, Viscidi RP, Bossis I, Stallings CR, Origoni AE, Sullens A, Yolken RH (2011) Coronavirus immunoreactivity in individuals with a recent onset of psychotic symptoms. Schizophr Bull 37(1):101-107

60. Deja M, Denke C, Weber-Carstens S, Schröder J, Pille CE, Hokema F, Falke KJ, Kaisers U (2006) Social support during intensive care unit stay might improve mental impairment and consequently health-related quality of life in survivors of severe acute respiratory distress syndrome. Crit Care 10(5):R147

61. Herridge MS, Moss M, Hough CL, Hopkins RO, Rice TW, Bienvenu OJ, Azoulay E (2016) Recovery and outcomes after the acute respiratory distress syndrome (ARDS) in patients and their family caregivers. Intensive Care Med 42(5):725-738

62. Iwashyna TJ, Ely EW, Smith DM, Langa KM (2010) Long-term cognitive impairment and functional disability among survivors of severe sepsis. Jama 304(16):1787-1794

63. Unroe M, Kahn JM, Carson SS, Govert JA, Martinu T, Sathy SJ, Clay AS, Chia J, Gray A, Tulsky JA (2010) One-year trajectories of care and resource utilization for recipients of prolonged mechanical ventilation: a cohort study. Ann Intern Med 153(3):167-175
64. Xu J, Zhong S, Liu J, Li L, Li Y, Wu X, Li Z, Deng P, Zhang J, Zhong N (2005) Detection of severe acute respiratory syndrome coronavirus in the brain: potential role of the chemokine mig in pathogenesis. Clin Infect Dis 41(8):1089-1096

65. Hopkins RO, Weaver LK, Collingridge D, Parkinson RB, Chan KJ, Orme JF Jr (2005) Two-year cognitive, emotional, and quality-oflife outcomes in acute respiratory distress syndrome. Am J Respir Crit Care Med 171(4):340-347

66. Hopkins RO, Weaver LK, Chan KJ, ORME JF (2004) Quality of life, emotional, and cognitive function following acute respiratory distress syndrome. J Int Neuropsychol Soc 10(7):1005-1017

67. Schelling G, Kapfhammer H-P (2013) Surviving the ICU does not mean that the war is over. Chest 144(1):1-3

68. Adhikari NK, Tansey CM, McAndrews MP, Matté A, Pinto R, Cheung AM, Diaz-Granados N, Herridge MS (2011) Selfreported depressive symptoms and memory complaints in survivors five years after ARDS. Chest 140(6):1484-1493

69. Bienvenu OJ, Colantuoni E, Mendez-Tellez PA, Shanholtz C, Dennison-Himmelfarb CR, Pronovost PJ, Needham DM (2015) Co-occurrence of and remission from general anxiety, depression, and posttraumatic stress disorder symptoms after acute lung injury: a 2-year longitudinal study. Crit Care Med 43(3):642-653

70. Cameron MJ, Ran L, Xu L, Danesh A, Bermejo-Martin JF, Cameron CM, Muller MP, Gold WL, Richardson SE, Poutanen SM (2007) Interferon-mediated immunopathological events are associated with atypical innate and adaptive immune responses in patients with severe acute respiratory syndrome. J Virol 81(16): 8692-8706

71. Ijomone OM, Olatunji SY, Owolabi JO, Naicker T, Aschner M (2018) Nickel-induced neurodegeneration in the hippocampus, striatum and cortex: an ultrastructural insight, and the role of caspase-3 and $\alpha$-synuclein. J Trace Elem Med Biol 50:16-23

72. Chen BP, Lane TE (2002) Lack of nitric oxide synthase type 2 (NOS2) results in reduced neuronal apoptosis and mortality following mouse hepatitis virus infection of the central nervous system. J Neurovirol 8(1):58-63

73. Chan PK, Tang JW, Hui DS (2006) SARS: clinical presentation, transmission, pathogenesis and treatment options. Clin Sci 110(2): 193-204

74. Zhang X, Wu K, Wang D, Yue X, Song D, Zhu Y, Wu J (2007) Nucleocapsid protein of SARS-CoV activates interleukin-6 expression through cellular transcription factor NF-KB. Virology 365(2): $324-335$

Publisher's note Springer Nature remains neutral with regard to jurisdictional claims in published maps and institutional affiliations. 